\section{JURNAL ABDIMAS

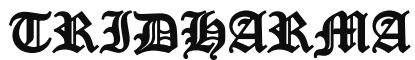

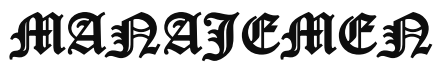

P-ISSN 2615-6849, E-ISSN 2716-070X

Jurnal ABDIMAS Vol.3,No.1,Desember 2021,Hal(115-123)

@ Prodi Manajemen Fakultas Ekonomi Universitas Pamulang

Email: abdimasjurnal.unpam@gmail.com Telp: (021) 741-2566

\title{
MENGEMBANGKAN KREATIVITAS ANAK DIMASA PANDEMI DENGAN MEMBUAT KARYA BERNILAI JUAL DARI BARANG BEKAS DIYAYASAN AL-KAMILAH
}

\author{
Wiwik Hasbiyah AN.,S.H.I.,M.A ${ }^{1}$, Dea Meita Putri², Dinda Audina Mulya³, Indah \\ Afriyanti $^{4}$, Kariza Manzila Aziz \\ ${ }^{1}$ Dosen Dan Mahasiswa Prodi Akuntansi Fakultas Ekonomi Universitas Pamulang \\ 2,3,4,5 Mahasiswa Prodi Akuntansi Fakultas Ekonomi Universitas Pamulang \\ Email : dosen00968@unpam.ac.id, meitaputridea@gmail.com, dindaaudinam44@gmail.com, \\ indahafriyanti328@gmail.com, karizamanzilaaziz99@gmail.com
}

\begin{abstract}
ABSTRAK
Covid-19 yang sudah lama terjadi di Indonesia dan sudah menyebar luas di seluruh Indonesia dapat dengan cepat melumpuhkan perekonomian serta pendidikan. Maka dari itu kita sebagai mahasiswa melakukan Pengabdian Kepada Masyarakat ini adalah untuk melaksanakan salah satu Tugas PKM di Perguruan Tinggi. Selain itu, melalui kegiatan Pengabdian Kepada Masyarakat ini mahasiswa diharapkan dapat memberikan kontribusi besar kepada pengembangan dan penerapan keilmuan dalam masyarakat di masa pandemi. Pendidikan yang tidak beraturan menyebabkan para pelajar dan mahasisea mengalami kesulitan dalam mengembangkan ilmu, khususnya untuk anak-anak usi dini. Hal ini dikarenkan mereka belum terlalu mengenal teknologi sehingga tidak dapat memanfaatkan teknologi tersebut guna untuk memperoleh pengetahuan. Pengetahuan yang mereka dapatkan hanya sebatas transfer ilmu yang dimiliki serta dikuasai olej orang tua mereka. Anak-anak yang sudah mengenal pendidikan seperti tergabung dalam lembaga pendidikan contohnya sekolah, pesantren, kelompok bimbingan belajar, dari lembaga pendidikan tersebut mereka sedikit banyak mendapatkan ilmu pengetahuan dari pembimbing dalam lembaga tersebut. Dalam hal ini banyak sekali orang tua khawatir akan kesehatan serta mereka gelisah dalam memberikan pendidikan untuk anak mereka. Dalam studi ini akan perkembangan kreativitas anak di masa pandemi khususnya dalam membuat sebuah karya salah satunya di dalam Kawasan Al-Kamilah. Murid-murid disana akan dibantung untuk mendorong lebih kreativitas mereka dalam berfikir luas terutama untuk menumbuhkan kreativitas dengan menggunakan bahan yang sederhana dan mudah untuk ditemukan contohnya barang bekas yang sudah tidak dipakai namun memiliki nilai jual yang tinggi. Adanya pemanfaatan barang bekas mampu menunjang kreativitas siswa sehingga dapat berfikir secara kreatif. Menjadi pembimbing yang dapat mengatasi semua permasalahan dalam pandemic Covid-19 hal ini dapat membantu anak-anak di Kawasan Al-Kamilah menjadi kreatif.
\end{abstract}

\section{Kata Kunci : Kreativitas, Barang Bekas, Pandemi Covid-19}

\begin{abstract}
Covid-19, which has been around for a long time in Indonesia and has spread throughout Indonesia, can quickly cripple the economy and education. Therefore, as students, we carry out this Community Service to carry out one of the PKM Tasks in Higher Education. In addition, through this Community
\end{abstract}




\section{JURNAL ABDIMAS

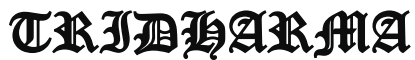

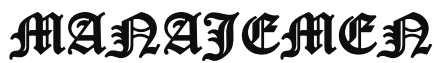

P-ISSN 2615-6849, E-ISSN 2716-070X

Jurnal ABDIMAS Vol.3,No.1,Desember 2021,Hal(115-123)

@ Prodi Manajemen Fakultas Ekonomi Universitas Pamulang

Email: abdimasjurnal.unpam@gmail.com Telp: (021) 741-2566

Service activity, students are expected to make a major contribution to the development and application of science in society during the pandemic.Irregular education causes students and students to experience difficulties in developing knowledge, especially for young children. This is because they are not too familiar with technology so they cannot use the technology to gain knowledge. The knowledge they get is only limited to the transfer of knowledge that is owned and controlled by their parents. Children who are familiar with education such as joining educational institutions such as schools, Islamic boarding schools, tutoring groups, from these educational institutions they get more or less knowledge from supervisors in these institutions. In this case a lot of parents are worried about their health and they are nervous about providing education for their children. In this study, the development of children's creativity during the pandemic, especially in making a work, is one of them in the Al-Kamilah Area. The students there will be assisted to encourage their creativity in broad thinking, especially to foster creativity by using materials that are simple and easy to find, for example used goods that are not used but have a high selling value. The use of used goods can support students' creativity so that they can think creatively. Being a mentor who can overcome all the problems in the Covid-19 pandemic, this can help children in the Al-Kamilah Area to be creative.

\section{Keywords: Creativity, Used Goods, Covid-19 Pandemic}

\section{PENDAHULUAN}

Anak-anak sangat menyukai kegiatan bermain, bersenang-senang dan melakukan tawa bersama teman mereka. Hal ini dapat membuat anak-anak bebas untuk memberikan ide ataupun mengemukakan gagasan tanpa adanya Batasan yang menghalangi, nermain sambal belajar merupakan kegiatan yang disukai oleh anak-anak dan dapat menumbuhkan kreativitas anak-anak tersebut, hal ini terjadi pada anak-anak di Yayasan AlKamilah. Menurut Momom Sudarman (2016:17) menjelaskan bahwasannya kreativitas merupakan kemampuan setiap orang untuk membuat sesuatu apakah itu dalam bentuk, ide, langkah, atau bentuk produk. Semua orang baik untuk anak-anak, orang dewasa sekalipun mempunyai naluri kreatif di dalam dirinya sama dengan anakanak yang memiliki potensi kreatif di dalam dirinya dan berbeda-beda. Namun dengan menunjang kreativitas yang dimiliki anakanak di Yayasan Al-Kamilah memerlukan sosok pendamping atau guru. Banyak cara yang dapat dilakukan oleh guru guna untuk mengembangkan kreatifitas yang dimiliki anak-anak di kawasan tersebut. Menjadi sosok guru harus dapat membimbing anak-anak dalam mengambangkan ilmu, sikap dan kreatifitas dalam diri mereka. Disinilah peran seorang pembimbing menjadi pembimbing yang professional kerena mereka adalah orang tua untuk anak-anak di Yayasan Al-Kamilah. Pembelajaran di Yayasan Al-Kamilah tentunya mengutamakan pertumbuhan dan perkembangan anak. Di dalam Peraturan Menteri Pendidikan dan Kebudayaan Nomor 146 tahun 2014 tentang Kurikulum 2013 Pendidikan Anak Usia Dini pada pasal 5 dinyatakan bahwa aspek-aspek pengembangan dalam kurikulum PAUD mencakup: nilai agama, nilai moral, fisikmotorik, kognitif, bahasa, sosial-emosional, dan seni. Dari aspek-aspek perkembangan pada anak yang sudah disebutkan, ada komponen pendukung yang sangat penting yaitu kreativitas. Kreativitas sebagai komponen integral dari lingkungan bermain kreatif yang membentuk fokus sentral dari 


\section{JURNAL ABDIMAS

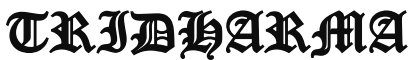

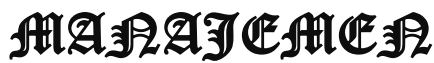

P-ISSN 2615-6849, E-ISSN 2716-070X

Jurnal ABDIMAS Vol.3,No.1,Desember 2021,Hal(115-123)

@ Prodi Manajemen Fakultas Ekonomi Universitas Pamulang

Email: abdimasjurnal.unpam@gmail.com Telp: (021) 741-2566 pengembangan kurikulum. Munandar (1987:88- 91) menyebutkan unsur-unsur untuk dapat mengetahui kreativitas pada anak yang meliputi keterampilan berpikir lancar, keterampilan kelenturan atau keluwesan (fleksibelitas), keterampilan berpikir orisinalitas, keterampilan memperinci (mengelaborasi), dan keterampilan menilai (mengevaluasi).

Pada saat masa pandemi seperti ini nampak adanya kesenjangan antara kebutuhan akan kreativitas dan perwujudannnya di dalam masyarakat khususnya dalam pendidikan di sekolah. Pendidikan di sekolah lebih berorientasi pada pengembangan, kecerdasan (intelegensi) daripada pengembangan kreativitas, sedangkan keduanya sama pentingnya untuk mencapai keberhasilan dalam belajar dan dalam hidup. Munandar (2014:15) menyatakan mengenai dasar-dasar yang menjadi pertimbangan dalam pengembangan kreativitas yaitu : Pertama, pendidik (guru dan orang tua) masih kurang memahami arti kreativitas yang meliputi ciri bakat dan non-bakat dan pengembangannya dalam tiga lingkungan (di rumah, di sekolah, dan di dalam masyarakat). Kedua, masih kurangnya pelayanan pendidikan khusus bagi mereka |yang berbakat istimewa sebagai sumber daya manusia berpotensi unggul padahal apabila mereka diberi kesempatan pendidikan yang sesuai dengan potensinya, dapat memberikan kontribusi yang bermakna kepada masyarakatnya. Ketiga, dalam pelayanan pendidikan bagi anak berbakat, pengembangan kreativitas sebagai salah satu faktor utama yang menentukan keberbakatan merupakan suatu tuntutan. Keadaan pandemi saat ini tidak mungkin untuk anak-anak di Yayasan Al-Kamilah untuk melakukan aktivitas di luar rumah terlebih jika bersama dengan teman banyak dan mengakibatkan kerumunan. Bermasin bersama-sama sebenarnya dapat mengasah daya ingat anak untuk mencegah kelupaan. Namun dengan kondisi pandemi seperti ini mengharuskan setiap anak untuk jaga jarak dan membuat kesuliatan dalam mengembangkan kreativitas dalam diri. Pada masa pandemic seperti ini membuat para guru di Kawasan Al-Kamilah berlomba-lomba untuk menumbukan perkemabangan kreatifitas untuk anak-anak disana.

Banyak hal yang dapat dilakukan untuk membantu dalam pengembangan kreativitas pada anak, salah satunya adalah memanfaatkan lingkungan sekitar seperti barang bekas (barang yang sudah tak terpakai) hal ini dilakukan anak-anak di Kawasan AlKamilah. Bahan limbah bisa dimanfaatkan oleh guru tanpa mengeluarkan banyak uang dan sering dijumpai pada lingkungan sekitar yang dapat dikreasikan lagi sebagai sesuatu yang dapat membantu dalam pengembangan kreativitas pada anak. Bahan limbah yang bisa digunakan seperti kertas koran, kain perca, kalender, plastik, kardus bekas, dan botol bekas (Hesti, 2014:65). Berdasarkan hasil observasi awal yang dilakukan ke beberapa anak yang ada di Yayasan Al-Kamilah, peneliti melihat aktivitas anak di rumah seperti beberapa anak sedang asik bermain game di gadget, beberapa anak yang memang aktivitasnya terbatas sehingga lebih banyak menghabiskan waktu untuk tidur, beberapa anak lainnya yang aktivitasnya hanya menonton tv, ada beberapa anak yang tetap belajar bersama orang tuanya, dsb. Pada masa pandemi covid-19 memang tidak ada aktivitas di luar rumah sehingga anak juga terbatas untuk sekolah dan bermain bersama temantemannya. Ketika anak diajak untuk bermain sambil membuat karya dengan melipat kertas sebagai bentuk kegiatan berpikir kreatif dalam menghasilkan karya dengan media kertas, ada anak yang masih terlihat bingung saat 


\section{JURNAL ABDIMAS

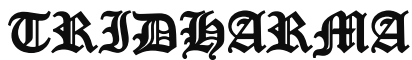

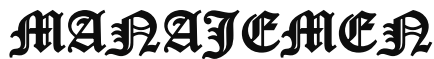

P-ISSN 2615-6849, E-ISSN 2716-070X

Jurnal ABDIMAS Vol.3,No.1,Desember 2021,Hal(115-123)

@ Prodi Manajemen Fakultas Ekonomi Universitas Pamulang

Email: abdimasjurnal.unpam@gmail.com Telp: (021) 741-2566 membuat karya, ada anak yang mengerjakannya dengan waktu yang cukup lambat sehingga karya yang dihasilkan hanya sedikit. Selain itu, beberapa anak lainnya sudah mengerjakan dengan lancar hanya saja hasil karyanya kurang bervariasi dan detail. Berdasarkan latar belakang yang telah diuraikan, penulis merasa tertarik untuk melakukan penelitian dengan memanfaatkan barang bekas berupa kertas bekas, kardus, dan gelas plastik untuk mengetahui tingkat berpikir kreatif anak dalam membuat karya dengan barang bekas.

\section{METODE PENELITIAN}

Adanya pandemi seperti ini membuat kita harus selalu produktiv dengan memanfaatkan waktu yang ada. Dalam metode dan strategi pengembangan kreativitas menggunakan metode ABCD Asset Based Community Development yaitu dengan lebih mengutamakan pemanfaatan asset dan potensi yang ada di lingkungan masyarakat di Yayasan Al-Kamalia. Anak-anak di Yayasan tersebut sebagai partisipasi aktif juga diharapkan untuk ikut serta dalam mengembangkan kegiatan sehingga dapat berjalan dengan baik. Dalam metode ini terdiri dari 5 jenis yaitu diantaranya.

\section{Menemukan (Discovery)}

Pada proses menemukan kegiatan pengembangan kreativitas anak dalam masa pandemi dilakukan dengan menggunakan cara proses percakapan yang mana dalam proses ini harus dijadikan sebuah penemuan yang sifatnya personal tentang apa yang menjadikan manfaat pada setiap individu yang memberikan sebuah perubahan dalam kegiatan. Tahap ini dimulai dengan memindahkan tanggung jawab pada perubagan kepada individu yang memiliki kepentingan dalam mengembangkan kreativitas anak-anak Yayasan. Kegiatan ini dilakukan dengan melakukan pendampingan dengan cara wawancara kepada anak-anak di Yayasan Al-Kamilah.

Dalam wawancara itu bertujuan untuk mengetahui potensi yang dimiliki anak-anak di dalam Yayasan tersebut. Ada beberapa tahap persiapan dalam kegiatan ini yaitu peneliti melakukan

- observasi, wawancara kepada pembimbing dan anak-anak Yayasan terkait proses dalam pengembangan kreativitas dari bahas bekas di masa pandemi.

- Menyampaikan strategi pendampingan yang dilakukan yaitu berupa pemanfaatn barang-barang bekas.

- Melakukan penyusunan materi dan kelengkapan peralatan dalam melakukan kegiatan.

\section{Impian (Dream)}

Setelah melakukan wawancara kepada anak-anak di Yayasan AlKamilah, tahap selanjutnya yaitu melakukan pendampingan dalam mengeambangkan kreativitas tiap anak disana. Proses selanjutnya dalam kegiatan pengabdian masyarakat yaitu kegiatan untuk memenuhi keterampilan setiap anak di Yayasan tersebut.

\section{Merancang (Design)}

Dalam proses untuk mengatahui tentang aset di Yayasan Al-Kamilah yang nantinya dimanfaatkan guna untuk memenuhi pengembangan dalam meningkatkan kreativitas anak- 


\section{JURNAL ABDIMAS

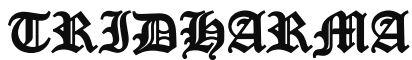

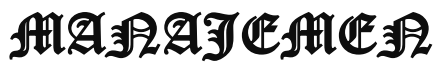

P-ISSN 2615-6849, E-ISSN 2716-070X

Jurnal ABDIMAS Vol.3,No.1,Desember 2021,Hal(115-123)

@ Prodi Manajemen Fakultas Ekonomi Universitas Pamulang

Email: abdimasjurnal.unpam@gmail.com Telp: (021) 741-2566 anak dari bahan bekas di masa pandemi.

\section{Menetukan (Defina)}

Dalam hal ini mahasiswa yang ikut dalam kegiatan pengabdian di masyarakat menjadi pemimpin untuk menentukan pilihan topik yang positif dengan tujuan proses deskripsi yang mengenai setiap perubahan yang diinginkan dalam melakukan pengembangan ini. Pendampingan terhadap anak-anak yang terlibat dalam Fokus Group Discussion (FGD). Dalam proses FGD pendampingan untuk anak-anak dalam menentukan fokus pembahasan yaitu melakukan perkembangan kreativitas untuk membuat barang dengan harga nilai jual tinggi dari bahan bekas. Proses FGD tersebut dapat dapat berjalan dengan lancar jika sudah dilakuka kesepakatan pembahasan yang akan dibahas di diskusi dalam perkembangan kreativitas anak di Yayasan AlKamilah. Pelaksanaan kegiatan ini diawali dengan melakukan pendekatan ke anak-anak Yayasan lalu memberikan edukasi kepada anak-anak itu bahwa dalam media pembelajaran yang dilaksanakan sangatlah berperan penting untuk diri mereka sendiri dan lingkungan sekitar yang perlunya memanfaatkan barang bekas untuk di daur ulang sebagai media meningkatkan kreativitas yang menyenangkan, karena kita tahu di masa pandemi ini pastinya membuat mereka bosan maka dari itu kita memberikan media pembelajaran yang membuat senang.

\section{Lakukan (Destiny)}

Serangkaian tindakan inspiratif yang mendukung proses belajar terus menerus dan inovasi tentang apa yang terjadi. Ini merupakan fase akhir untuk memfokuskan cara untuk melangkah maju. Langkah terakhir dalam melaksanakan kegiatan yang sudah disepakati untuk memenuhi impian setiap anak di Yayasan itu. Teori pada dasarnya pentunjuk dalam memecahkan suatu masalah yang ada di Yayasan itu. Dalam melakukan pengembangan kreativitas anak untuk menciptakan barang dengan nilai jual tinggi. Pada tahap evaluasi dikasi apa yang terlaksana dengan baik maupun yang masih kurang dalam proses belajar mengajar yang memanfaatkan barang-barang bekas.

\section{Khalayak Sasaran}

Peserta kegiatan : Anak-anak di lingkungan Yayasan Al-Kamilah

\section{Tempat}

Tempat Kegiatan di Yayasan Al-Kamilah

\section{Metode Kegiatan}

Metode yang digunakan dalam kegiatan Pengabdian Kepada Masyarakat (PKM) ini adalah melalui kegiatan pengembangan kreativitas anak-anak di Yayasan Al-Kamilah:

a. Mengembangan kreativitas anak-anak di masa pandemi dengan menghasilkan barang yang bernilai jual tinggi dan berasal dari barang bekas.

Adapun metode sebelum dan sesudah pelaksanaan PKM, adalah sebagai berikut :

\section{1). Metode Pengumpulan Data}

Untuk memperoleh data yang akurat yang dapat dipercaya kebenarannya dan relevan, 


\section{JURNAL ABDIMAS

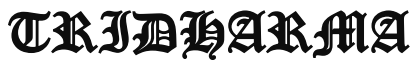

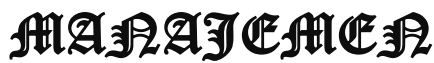

P-ISSN 2615-6849, E-ISSN 2716-070X

Jurnal ABDIMAS Vol.3,No.1,Desember 2021,Hal(115-123)

@ Prodi Manajemen Fakultas Ekonomi Universitas Pamulang

Email: abdimasjurnal.unpam@gmail.com Telp: (021) 741-2566 maka pengumpulan data dilakukan dengan beberapa metode yaitu :

a. Wawancara

Merupakan proses untuk memperoleh data dengan cara melakukan pertanyaan, kepada anak-anak di Yayasan AlKamilah.

b. Observasi

Merupakan proses pengumpulan data dengan mengadakan pengamatan langsung pada objek Pengabdian Kepada Masyarakat (PKM) untuk memperoleh data yang diperlukan, dengan melakukan survey langsung ke tempat PKM.

c. Fokus Grup Diskusi (FGD)

Merupakan proses pengumpulan data dengan cara diskusi kelompok secara sistematis dan terarah mengenai pokok permasalahn Pengabdian Kepada Masyarakat (PKM). Dalam hal ini FGD dilakukan dengan

d. Dokumen

Dokumen merupakan catatan peristiwa yang sudah berlalu, biasanya berbentuk tulisan, gambar, atau karya-karya monumental dari seseorang. Studidokumen merupakan pelengkap dari penggunaan observasi dan wawancara. Dalam hal ini dilakukan dokumentasi berupa surat menyurat melakukan PKM

\section{Metode Pelaksanaan}

Metode pelaksanaan kegiatan ini berupa penyuluhan kepada anak-anak di Yayasan Al-Kamilah, Adapun tahapan yang dilakukan adalah sebagai berikut :

\section{Tahap Persiapan}

Tahap persiapan yang dilakukan meliputi : a. Informasi awal, pada tahap ini didapatkan infomasi awal dari salah satu Pembina disana yang menginformasikan bahwa anak siap untuk melakukan pembelajaran mengenai perkembangan.

b. Pemantapan dan penentuan lokasi dan sasaran. Setelah informasi awal maka ditentukan lokasi pelaksanaan dan sasaran peserta kegiatan penyuluhan. Dengan melakukan proses perijinan secara lisan terlebih dahulu untuk diadakan PKM di lokasi tersebut.

c. Penyusunan bahan/materi penyuluhan yang meliputi: slide presentasi (power point) dan makalah/materi untuk kegiatan penyuluhan berupa materi mengenai pembuatan barang dari barang bekas.

3) Tahap Pelaksanaan Penyuluhan

Tahap ini akan menjelasan tentang materi yang akan disampaikan oleh mahasiswa Universitas Pamulang mana sesi ini menitikberatkan pada pemaparan materi mengenai pengembangan kreativitas anak di masa pandemi dengan membuat karya bernilai jual dari barang bekas.

4) Metode tanya jawab sangat penting bagi para peserta pelatihan. Metode ini memberi kesempatan kepada anak-anak di Yayasan Al-Kamilah untuk menanyakan hal-hal yang masih kurang atau belum jelas dalam penyuluhan yang sudah disampaikan.

\section{HASIL DAN PEMBAHASAN}

Mahasiswa di dalam melakukan penyuluhaan sangat bersemangat serta antusias dengan kegiatan yang diadakan. Disamping itu masa pandemi seperti ini membuat ilmu dan keterampilan anakanak semakin berkurang jadi dengan mendapatkan informasi baru yang detail 


\section{JURNAL ABDIMAS

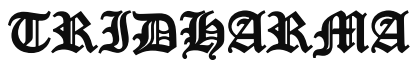

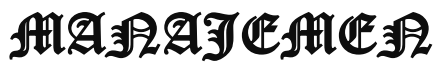

P-ISSN 2615-6849, E-ISSN 2716-070X

Jurnal ABDIMAS Vol.3,No.1,Desember 2021,Hal(115-123)

@ Prodi Manajemen Fakultas Ekonomi Universitas Pamulang

Email: abdimasjurnal.unpam@gmail.com Telp: (021) 741-2566 tentang pembahasan mengenai pengembangan-pengembangan

kreativitas untuk mengasah kemampuan setiap anak. Di dalam tanya jawab peserta cukup banyak bertanya tentang cara memanfaatkan barang bekas dengan baik dan bernilai jual tinggi, lalu juga banyak yang menanyakan terkait kegiatan produktiv yang dilakukan di masa pandemic guna meningkatkan skill. Pada tahap akhir dilakukan pengisian angket/kuesioener mengenai pemahaman kegiatan mengembangkan minat anakanak dalam Yayasan Al-Kamilah, sebagai tolak ukur hasil kegiatan PKM ini bisa bermanfaat untuk para mahasiswa. Kegiatan ini intinya berupa penyuluhan dengan penyampaian materi tentang dasar-dasar pengefektivan kegiatan daring maupun offline dengan tujuan untuk mengetahui secara optimal bagaimana anggota memahami peran sebagai mahasiswa , selanjutnya dilakukan tahap diskusi dan tanya jawab. Penyampaian materi diberikan oleh tim PKM..

\section{Perkembangan Kreativitas Anak dalam Pemanfaatan Barang Bekas.}

Agar anak lebih memahami materi yang disampaikan mengenai pemanfaatan barang bekas untuk menjadi barang dengan nilai tinggi, anak-anak diberi pembelajaran dengan media, media pembelajaran yang digunakan untuk menyalurkan meteri kepada anak-anak di Yayasan tersebut. Diantaranya media yang telah siswa buat yaitu pemanfaatan kertas bekas sebagai media belajar tata surya, Tata surya dalam bahasa inggris disebut solar system terdiri dari sebuah bintang yang disebut matahari dan semua objek yang yang mengelilinginya. Pengertian tata surya yang lain adalah kumpulan benda-benda langit dimana matahari sebagai pusatnya. pada tahap awal, siswa belajar tentang pengertian dan macam-macam tata surya melalui video audio visual, siswa mencatat halhal yang telah dipelajari sebagai hasil pembelajaran.

Selanjutnya siswa membuat tata surya dari kertas bekas dengan langkahlangkah sebagai berikut: 1 . Menyiapkan alat-alat yang akan di pergunakan seperti kertas bekas lem, air, cat warna, dan kertas pelangi (hitam), 2. Langkah pertama, melarutkan kertas bekas ke dalam air sampai menjadi bubur kertas, 3 . Langkah kedua membentuk kertas bubur menjadi bulatan- bulatan menyerupai planet, 4. Langkah ketiga, men geringkan bola-bola planet dengan bantuan matahari, 5. Langkah keempat, memberikan warna sesuai dengan warna planet. Langkah terahir, menempelkan bola-bola planet pada kertas pelangi sesuai dengan orbit lintasan dan susunan letak planet, agar planet tersebut mudah diingat siswa memberikan nama- nama planet di samping bola-bola planet tersebut.

$\begin{array}{lcr}\text { Melakukan } & \text { pendampingan } & \text { dalam } \\ \text { kegiatan } & \text { memberikan } & \text { materi } \\ \text { perkembangan } & \text { kreativitas } & \text { juga } \\ \text { mengetahui cara atau metode } & \end{array}$

e untuk menyampaikan ilmu pengetahuan untuk anak-anak dengan cara yang berbeda. Selain menyampaikan ilmu pengetahuan dengan cara memakai peraga menggunakan bahan bekas seperti yang dijelaskan diatas, pendamping juga bisa menggunakan cara tebak kata dimana tebak kata ini menjadi salah satu penyampaian ilmu pengetahuan yang menyenangkan dan seru bagi anak-anak di Yayasan tersebut. Tebak kata berisi 


\section{JURNAL ABDIMAS

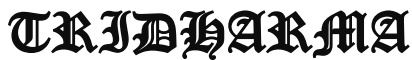

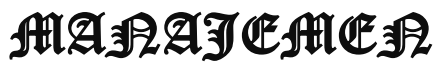

P-ISSN 2615-6849, E-ISSN 2716-070X

Jurnal ABDIMAS Vol.3,No.1,Desember 2021,Hal(115-123)

@ Prodi Manajemen Fakultas Ekonomi Universitas Pamulang

Email: abdimasjurnal.unpam@gmail.com Telp: (021) 741-2566 pertanyaan-pertanyaan yang disiapkan oleh pendamping untuk anak-anak. Alat peraga seperti kerajinan membuat tata surya dengan bahan bekas diatas bisa diberi pertanyaan, misalnya dibalik gambar salah satu tata surya seperti bumi diberi pertanyaan berapa rotasi planet bumi mengelilingi matahari selama satu jam ?. Atau bisa juga pendamping langsung memberikan pertanyaan-pertanyaan tentang ilmu astronomi yang telah dibuat alat peraganya diatas. Atau menggunakan cara metode dragon ball, dragon ball meerupakan model pembelajaran dengan cara siswa memberikan pertanyaan kepada anak-anak dengan cara ini anak-anak bisa belajar terlebih dahulu untuk mempersiapkan pertanyaan dan jawabannya

sebelum ditanya oleh pendamping belajar atau siswa lainnya.

\section{PENUTUP}

Berdasarkan analisis yang dilakukan dapat ditarik kesimpulan bahwa kegiatan pengabdian ini dengan memberikan perkembangan pada anak-anak Yayasan sangatlah efektif dan memberikan banyak sekali dampak positif bagi anak-anak disana, Berdasarkan kegiatan mengembangkan kreativitas anak di masa pandemi dengan membuat karya bernilai jual dari barang bekas di yayasan Al-Kamilah. yang telah dilaksanakan, dapat ditarik kesimpulan bahwa anak-anaknya dapat meningkatkan minat dan kreaktifitas siswa dengan memanfaatkan barang-barang bekas. Anak-anak di Yayasan ini memiliki bekal pengetahuan dan pengalaman baru dalam pendampingan pembelajaran yang telah dilaksanakan. Siswa memiliki kepedulian terhadap lingkungan dengan memanfaatkan barang-barang bekas yang bisa di daur ulang dan mendapatkan nilai jual yang tinggi.

\section{DAFTAR PUSTAKA}

Badru Zaman, dkk. 2007. Media dan Sumber Belajar TK. Jakarta: Penerbit Universitas Terbuka.

Hasby Sjamsir, Farny Sutriany Jafar , Annisa Nurjanah. (2018). Peningkatan Kreativitas Anak Usia 5-6 Tahun Melalui Pemanfaatan Barang Bekas Di Tk Islam Al-Kautsar Samarinda. Universitas Mulawarman, Samarinda, Indonesia. JECES. Early Childhood Education Journal of Indonesia.1 (2).

Herliandry, L. D., Nurhasanah, N., Suban, M. E., \& Kuswanto, H. (2020). Pembelajaran pada masa pandemi covid-19.JTP-Jurnal Teknologi Pendidikan,22(1), 65-70.

Hijriati. (2017). Peranan Dan Manfaat Ape Untuk Mendukung Kreativitas Anak Usia Dini. Bunayya. Jurnal Pendidikan Anak. 3 (2). 59-69

Pasaribu, V. L. D., Agrasadya, A., Shabrina, N., \& Krisnaldy, K. (2020). Menjadi Enterpreneur Muda Yang Memiliki Jiwa Leadership Untuk Menghadapi Masa Depan. Abdi Laksana: Jurnal Pengabdian Kepada Masyarakat, 1(1).

Pasaribu, V. L. D., Susanti, F., \& Hartuti, E. T. K. (2019). Memotivasi Siswa dan Siswi SMK Letris Indonesia di Dalam Menentukan Pilihan Untuk Melanjutkan Pendidikan Atau Bekerja Setelah Lulus Sekolah. Jurnal Pengabdian Dharma Laksana, 1(2), 161-172.

Pasaribu, V. L. D., Sulaiman, S., Sutiman, S., Thaharudin, T., \& Purnomo, B. Y. (2020). Pengenalan Letak Posyandu Terdekat Dikelurahan Pisangan Dengan Manajemen Pemasaran Revolusi 4.0 Untuk Meningkatkan 


\section{JURNAL ABDIMAS

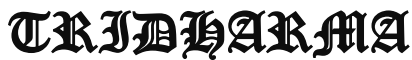

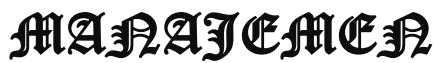

P-ISSN 2615-6849, E-ISSN 2716-070X

Jurnal ABDIMAS Vol.3,No.1,Desember 2021,Hal(115-123)

@ Prodi Manajemen Fakultas Ekonomi Universitas Pamulang

Email: abdimasjurnal.unpam@gmail.com Telp: (021) 741-2566
Pengetahuan Masyarakat Letak Dan Fungsi Posyandu Terdekat Pada Kelurahan Pisangan. Dedikasi Pkm, 1(1), 105-110.

Pasaribu, V. L. D., Oktrima, B., Prabowo, B., Arianto, N., \& Haryoko, U. B. (2020). Progam Pendampingan Dan Penyelenggaraan Pendidikan Anak Pada Usia Dini Terhadap Prestasi Belajar Dilingkungan Rt 020 Rw 009. Kel Giri Peni. Kec Wates. Yogyakarta. Jurnal Lokabmas Kreatif, 1(1), 71-75.

Pasaribu, V. L. D., Jannah, M., Fazar, M., Putra, S. P., Monalisa, M., \& Sofa, M. (2021). MENINGKATKAN PRODUKTIVITAS USAHA DIMASA PANDEMI PADA IBU PKK RT 004/003 KELURAHAN SAWAH BARU CIPUTAT, TANGERANG SELATAN. Abdi Laksana: Jurnal Pengabdian Kepada Masyarakat, 2(2), 295-301.

Pasaribu, V. L. D., Yuniati, H. L., Pranata, R., Sembayu, R., Purba, S. M., \& Nurbayani, T. T. A. (2021). MANAJEMEN KEUANGAN UNTUK MENGHADAPI DAN BERTAHAN DI ERA COVID 19. Jurnal Abdimas Tri Dharma Manajemen, 2(2), 12-18.

Pasaribu, V. L. D., Dwiyatni, A., Sabina, C., Ridwan, M., Gunawan, D. D., \& Noviani, B. C. (2021). EVALUASI PENERAPAN 3M DIMASA PANDEMIC COVID 19. Jurnal Abdimas Tri Dharma Manajemen, 2(2), 54-60.

Pasaribu, V. L. D., Syafei, A. N., Farhan, A., Aufaizah, A., Irani, C., \& Firtiayani, S. R. (2021). PENGARUH DISPLIN

PROTOKOL KESEHATAN
TERHADAP PENCEGAHAN
PENULARAN VIRUS
19. Jurnal Abdimas Tri
Manajemen, 2(2), 91-98.

Pasaribu, V. L. D., Septiani, F., Rahayu, S., Lismiatun, L., Arief, M., Juanda, A., ... \& Rahim, R. (2021). Forecast Analysis of Gross Regional Domestic Product based on the Linear Regression Algorithm Technique.

Priadi, A., Pasaribu, V. L. D., Virby, S., Sairin, S., \& Wardani, W. G. (2020). Penguatan Ekonomi Kreatif Berbasis Sumber Daya Desa Dikelurahan Rempoa. Abdi Laksana: Jurnal Pengabdian Kepada Masyarakat, 1(3), 356-35

Pasaribu, V. L. D., Priadi, A., Anismadiyah, V., Rahayu, S., \& Maduningtias, L. (2021). PENYULUHAN KREATIF DAN INOVATIF MENINGKATKAN MUTU PRODUKSI UMKM DI DESA BELEGA KABUPATEN GIANYAR. Pro Bono Jurnal Pengabdian Kepada Masyarakat, 1(02).

Pasaribu, V. L. D. (2021). PELATIHAN BERBASIS ONLINE DI ERA COVID-19. Jurnal Abdimas Tri Dharma Manajemen, 2(3), 26-32.

Pasaribu, V. L. D., \& Setyowati, R. (2021). ADAPTASI KEHIDUPAN NEW NORMAL PADA MASA PANDEMI COVID-19 DIYAYASAN PONDOK PESANTREN DAN PANTI ASUHAN NURUL IKHSAN KECAMATAN SETU, KOTA TANGERANG SELATAN. Jurnal Lokabmas Kreatif: Loyalitas 


\section{JURNAL ABDIMAS

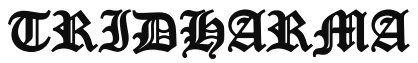

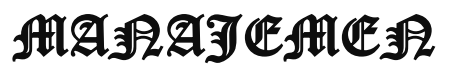

P-ISSN 2615-6849, E-ISSN 2716-070X

Jurnal ABDIMAS Vol.3,No.1,Desember 2021,Hal(115-123)

@Prodi Manajemen Fakultas Ekonomi Universitas Pamulang

Email: abdimasjurnal.unpam@gmail.com Telp: (021) 741-2566
Kreatifitas Abdi Masyarakat Kreatif, 2(2), 82-88.
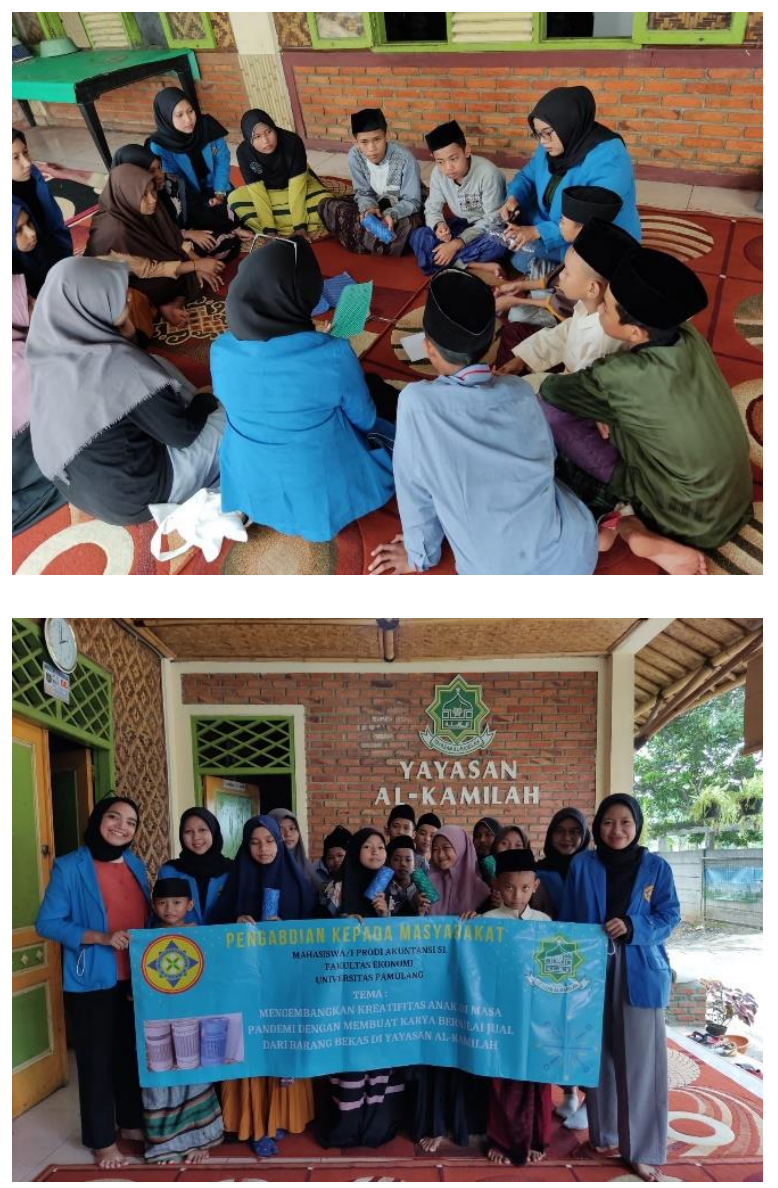

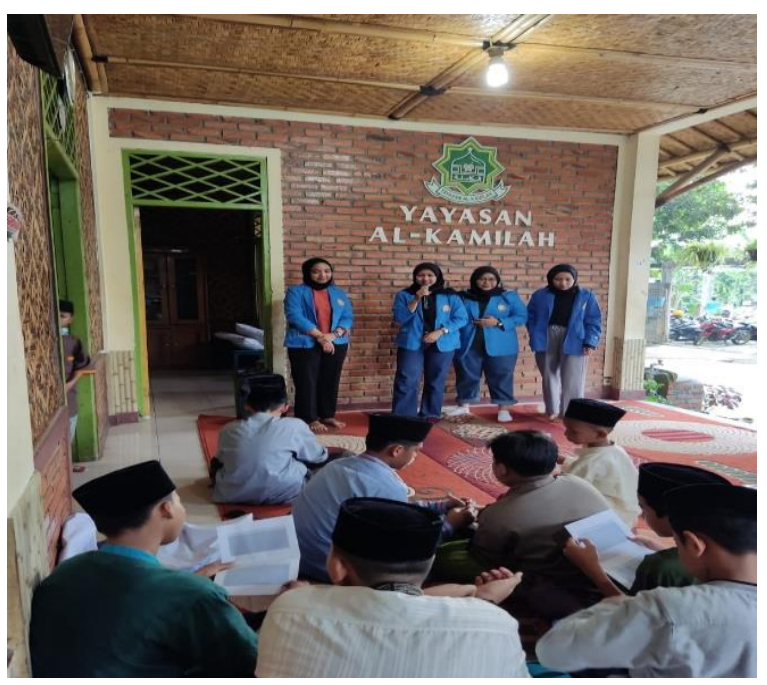

